\title{
RESPONSE OF POTATO PLANTS TO POTASSIUM AND MICRONUTRIENT FERTILIZATION
}

\author{
Dalia A. Sayed \\ Soils, Water and Environ. Res., Institute, Agric. Res. Center, Giza, Egypt \\ Received: Jun. 6, 2016 \\ Accepted: Jul. 4, 2016
}

\begin{abstract}
Two field experiments were conducted on sandy soil at El-Sharawy Village in EL-Bostan area, Noubaria region, Elbeheira Governorate (Latitude $30^{\circ} 43^{\prime} 22.01^{\prime \prime} \mathrm{N}$, Longitude $30^{\circ} 16^{\prime} 44.50^{\prime \prime}$ E), Egypt, during two successive winter seasons of 2013/2014 and 2014/2015 to study the effect of $\mathrm{K}_{2} \mathrm{O}$ levels i.e. $\left(50,75\right.$ and $100 \%$ of the recommended rate $96 \mathrm{~kg} \mathrm{~K} \mathrm{~K}_{2} \mathrm{O} / \mathrm{fed}$ ) along with foliar spraying with $1 \% \mathrm{~K}_{2} \mathrm{O}(2 \% \mathrm{~K}$-sulphate) and/or mixture of $\mathrm{Fe}(150 \mathrm{ppm})$, $\mathrm{Zn}(75 \mathrm{ppm})$ and $\mathrm{Mn}(75 \mathrm{ppm})$ on the growth, productivity, yield characters and quality of potato plants $\mathrm{cv}$. Spunta. The results showed that plant height, foliage fresh and dry weight/plant, total yield, tuber number and yield per plant were affected by $K$ supply. Raising $K$ level up to $96 \mathrm{~kg}$ $\mathrm{K}_{2} \mathrm{O} /$ fed significantly increased the above mentioned vegetative growth parameters and total yield. Tuber yield and quality of potato plants were significantly higher when soil and foliar application of $1 \% \mathrm{~K}_{2} \mathrm{O}$ and lor micronutrients were combined. The best results were achieved with foliar application of $1 \% \mathrm{~K}_{2} \mathrm{O}$ and micronutrients together with a basal fertilization of $96 \mathrm{~kg}$ $\mathrm{K}_{2} \mathrm{O} / \mathrm{fed}$. Similarly, macronutrients ( $\mathrm{N}, \mathrm{P}$ and $\mathrm{K}$ ) and micronutrient ( $\mathrm{Fe}, \mathrm{Zn}$ and $\mathrm{Mn}$ ) content in tubers recorded the highest values when soil and foliar application were combined. The interaction between foliar application of $1 \% \mathrm{~K}_{2} \mathrm{O}$ and micronutrients combined with 72 or $96 \mathrm{~kg}$ $\mathrm{K}_{2} \mathrm{O}$ soil application produced significantly high vegetative growth characteristics, tuber yields and quality of potato plants with no significant difference between the two rates 72 and $96 \mathrm{~kg}$ $\mathrm{K}_{2} \mathrm{O}$.
\end{abstract}

Key words: Foliar application, Micronutrients, Potassium, Potato, Soil application, Tuber yield and quality.

\section{INTRODUCTION}

Potato (Solanum tuberosum L.) is a good source of carbohydrates, protein, vitamin C, fiber, minerals and it is low in fat (Navarre et al., 2009). One important factor during cultivation influencing tuber yield and quality is an adequate and balanced fertilizer supply. Responses of potato to fertilizer rate vary with location, cultivar, application time, and rate and type of fertilizer (Westermann, 2005). Among the major nutrients, potassium $(K)$ is required by potato in high amounts due to its important role on plant physiology. $\mathrm{K}$ contributes to many aspects, for example it stimulates enzyme activities, promotes protein synthesis, improves photosynthesis, supports on osmoregulation, regulates opening and closure of stomata and participate on nutrients translocation (Marschner, 1995and Mengel, 2007). With regard to these functions, an adequate supply of $\mathrm{K}$ in the potato plant dictates improvements of tubers quality, such as increasing total yield and yield of processed-grade tubers, decreasing black spot susceptibility and hollow heart, improving processing properties and chips color as well as increasing plant resistance to disease, pathogens and environmental stresses (Roemheld and Kirkby, 2010). K plays an important role in tuber yield and quality due to its high mobility in plant tissues (Mengel and Kirkby, 2001).

Foliar fertilization is a supplemental nutrition with macro and micro- nutrients. Foliar nutrition is ideally designed to provide 
many elements in conditions that may be limiting production at a time when nutrient uptake from the soil is inefficient or nonexistent (Hiller, 1995). Foliar sprays, itself is effective for most nutrients in correcting foliar deficiencies, but not effective to correct tuber nutritional problems if the nutrient is not mobile in the phloem (Westennann,2005). Therefore, foliar feeding of nutrients has become an established procedure in crop production to increase yield and quality of crop products (Roemheld and El-Fouly,1999) and it also minimizes environmental pollution and improves nutrient utilization through reducing the amounts of fertilizers added to the soil (Abou-El-nour, 2002). In addition, foliar applications of $\mathrm{K}$ can improve yield and tuber quality, especially in heavy clay or in sandy soils where $\mathrm{K}$ is not readily available for the plants.

The objective of the present work was to study the effect of $\mathrm{K}$-fertilization rates as soil application along with foliar $\mathrm{K}$ and/or micronutrients on the growth, productivity, yield characters and quality of potato plants under sandy soil conditions.

\section{MATERIALS AND METHODS}

Two field experiments were conducted on sandy soil at El-Sharawy Village in ELBostan area, Noubaria region, Elbeheira Governorate (Latitude 30 43' 22.01" N, Longitude $30^{\circ} 16^{\prime} 44.50 "$ E), Egypt, during two successive winter seasons of 2013/2014 and $2014 / 2015$ to study the effect of $\mathrm{K}$ level i.e. $(50,75$ and $100 \%$ of the recommended doses $96 \mathrm{~kg} \mathrm{~K} \mathrm{~K}_{2} \mathrm{O} / \mathrm{fed}$ ) individually and in combined with foliar spraying of $1 \%$ $\mathrm{K}_{2} \mathrm{O}(2 \% \mathrm{~K}$-sulphate) and/or a mixture of $\mathrm{Fe}$ (150ppm), Zn(75ppm) and Mn(75ppm)and their interactions on the growth, productivity, yield characters and quality of potato plants cv. Spunta. Representative soil surface sample $(0-30 \mathrm{~cm})$ was taken from the experimental site before sowing and prepared to determine some physical and chemical properties according to Klute (1986) and Page et al. (1982) as shown in Table (1).

\section{Experimental design}

The experimental design was split plot in randomized blocks with three replicates. Each experiment included 12 treatments. Each sub plot consisted of 4 ridges $(3.5 \mathrm{~m}$ long and $0.75 \mathrm{~m}$ apart) occupying an area of $10.5 \mathrm{~m}^{2}$. All plots were fertilized with $\mathrm{N}$ fertilizer at the rate of $150 \mathrm{~kg} \mathrm{~N} / \mathrm{fed}$ as ammonium nitrate $(33.5 \% \mathrm{~N})$, which was added in three equal doses, after 4, 6 and 8 weeks from planting. Phosphorus was also applied to all plots during the soil preparation as calcium superphosphate $\left(15 \% \mathrm{P}_{2} \mathrm{O}_{5}\right)$ at the rate of $75 \mathrm{~kg} \mathrm{P}_{2} \mathrm{O}_{5} /$ fed. Potassium with three levels i.e. ( 50,75 and $100 \%$ of the recommended doses ( $96 \mathrm{~kg}$ $\mathrm{K}_{2} \mathrm{O} / \mathrm{fed}$.) were randomly distributed in the main plots and added in two equal doses with the first and third doses of $\mathrm{N}$ fertilizer. The sub plots were occupied by control, foliar treatments of $1 \% \quad \mathrm{~K}_{2} \mathrm{O} \quad(2 \% \mathrm{~K}$ sulphate)and/ or mixture of micronutrients in chelated form as Fe-EDTA $(13 \% \mathrm{Fe}), \mathrm{Mn}$ $\operatorname{EDTA}(15 \% \mathrm{Mn})$ and $\mathrm{Zn}-\operatorname{EDTA}(15 \% \mathrm{Zn})$ with the concentration of $150 \mathrm{ppmFe}, 75 \mathrm{ppmMn}$ and $75 \mathrm{ppmZn}$.The plants received three sprays at 45,60 and 75 days after planting with spraying solution volume of $400 \mathrm{~L} / \mathrm{fed}$ in each, spray for the mixture of micronutrients alone or combined with and mixture of micronutrients with foliar application $1 \% \mathrm{~K}_{2} \mathrm{O}$ since both $\mathrm{K}$ and micronutrient mixture were simultaneously sprayed.

\section{Data recorded:}

\section{Vegetative growth parameters}

At 90 days after planting (DAP), a random sample of six plants from each plot was taken to measure plant height, number of main stems/plant, foliage fresh and dry weight /plant (g). 
Table 1: Some physical and chemical properties of the experiment of soil before sowing (Mean of two seasons).

\begin{tabular}{|c|c|c|c|c|c|c|c|c|c|c|c|}
\hline \multicolumn{5}{|c|}{ Particle size distribution } & \multirow{2}{*}{\multicolumn{2}{|c|}{$\begin{array}{c}\mathrm{OM} \\
\%\end{array}$}} & \multirow{2}{*}{\multicolumn{2}{|c|}{$\underset{\%}{\mathrm{CaCO} 3}$}} & \multirow[b]{2}{*}{$\mathrm{PH}$} & \multirow{2}{*}{\multicolumn{2}{|c|}{$\begin{array}{c}\mathrm{EC} \\
\mathrm{dSm}-1\end{array}$}} \\
\hline $\begin{array}{c}\text { Coarse } \\
\text { sand } \\
\%\end{array}$ & $\begin{array}{c}\text { Fine } \\
\text { sand } \\
\%\end{array}$ & $\begin{array}{l}\text { Silt } \\
\%\end{array}$ & $\begin{array}{c}\text { Clay } \\
\%\end{array}$ & $\begin{array}{l}\text { Texture } \\
\text { class }\end{array}$ & & & & & & & \\
\hline 52.2 & 39.3 & 5.4 & 3.1 & Sand & \multicolumn{2}{|c|}{0.16} & \multicolumn{2}{|l|}{3.5} & 8.1 & & 0.41 \\
\hline \multicolumn{8}{|c|}{$\begin{array}{l}\text { Soluble cations and anions in the soil paste extract, } \\
\text { (meq } / 100 \mathrm{~g} \text { soil) }\end{array}$} & \multicolumn{4}{|c|}{$\begin{array}{l}\text { Available nutrients } \\
(\mathrm{mg} \mathrm{kg}-1)\end{array}$} \\
\hline \multicolumn{4}{|c|}{ Cations } & \multicolumn{4}{|c|}{ Anions } & \multirow[b]{2}{*}{$\mathrm{N}$} & \multirow[b]{2}{*}{$P$} & \multirow[b]{2}{*}{$\mathrm{K}$} & \multirow[b]{2}{*}{$\mathrm{Zn}$} \\
\hline $\mathrm{Ca}++$ & $\mathrm{Mg}^{++}$ & $\mathrm{Na}^{+}$ & $\mathrm{K}^{+}$ & $\mathrm{CO} 3^{--}$ & $\mathrm{HCO}^{-}$ & $\mathrm{Cl}^{-}$ & SO4-- & & & & \\
\hline 1.61 & 1.28 & 1.02 & 0.18 & -- & 1.53 & 1.92 & 0.64 & 15 & 6.5 & 85 & 0.7 \\
\hline
\end{tabular}

\section{2-Tubers yield and quality:}

At harvest (120 DAP), the following items were determined: number of tubers/plant, average tuber weight $(\mathrm{g})$ and tuber yield (Ton/fed), as well as tuber quality parameters, i.e. dry matter (\%), specific gravity, starch, total carbohydrate and protein \%.

Specific gravity (SG): 5 tubers per plot were sampled to determine the specific gravity using the method of weight in water (Ww) and weight in air (Wa) described by Talburt and Smith (1975), as follow:

$[S G=W a /(W a-W w)]$

\section{3-Chemical determinations}

Tuber parts were dried at $70{ }^{\circ} \mathrm{C}$ for $48 \mathrm{hrs}$ and then wet digested using sulphuric and per chloric acids mixture according to Chapman and Pratt (1961). Total N was determined using the modified micro Kjeldhal method (Cottenie et al. 1982) and $P$ by colorimetric method using spectrophotometer (Ryan et al. 1996). Potassium content was measured using a flame photometer method as described by Chapman and Pratt (1982). Fe, Mn and Zn concentration were determined by using atomic absorption spectrophotometer
(Chapman and Pratt, 1961) .Quality parameters analyzed included starch, total carbohydrate, crude protein, and dry matter content. Total carbohydrates were determined by using a colorimetric method as described by Dubois et al. (1956). The crude protein concentration was calculated by multiplying total nitrogen concentration by the factor of 5.75. Total dry matter was determined by oven drying at $70^{\circ} \mathrm{C}$ to a constant mass.

All the collected data obtained were subjected to statistical analysis according to Gomez and Gomez (1984).

\section{RESULTS AND DISCUSSION 1-Vegetative growth parameters}

Data presented in Table (2) indicate that the studied vegetative growth parameters of potato, i.e., plant height, foliage fresh and dry weight /plant (g) were significantly increased by increasing $\mathrm{K}$ fertilizer rate, while the number of stems / plant was not significantly influenced as shown in Table (2). This could be due to the importance of $K$ as an essential nutrient required for many metabolic processes and its role cannot be substituted by other nutrients (Westermann, 2005). This increment may be also due to the 
role of potassium in plant nutrition, i.e. promotion of enzymes activity and enhancing the translocation of assimilates and protein synthesis. In this regard Asmaa and Magda (2010) found that the vegetative growth parameters of potato, i.e. plant length, foliage fresh weight /plant and dry weight of leaves and shoots were gradually and significantly increased by increasing the level of potassium application.

Moreover, data in Table (2) show that foliar application of $1 \% \mathrm{~K}_{2} \mathrm{O}$ combined with $96 \mathrm{~kg} \mathrm{~K} \mathrm{~K}_{2} \mathrm{O} / \mathrm{fed}$ as soil application produced the highest plant length, foliage fresh and dry weight of plant and these were significantly better than the same treatment with mixture $\mathrm{Fe}, \mathrm{Zn}$ and $\mathrm{Mn}$. Thus, when $\mathrm{K}$ foliar spray was applied along with soil K, the vegetative growth parameters were significantly higher than the soil application alone.

Table 2. Effects of soil and foliar applications of potassium and micronutrients and their interactions on vegetative growth characteristics (mean of two seasons)

\begin{tabular}{|c|c|c|c|c|c|}
\hline \multicolumn{2}{|c|}{ Treatments } & \multirow{2}{*}{$\begin{array}{c}\text { Plant } \\
\text { height }(\mathrm{cm})\end{array}$} & \multirow{2}{*}{$\begin{array}{l}\text { No. of main } \\
\text { stems/plant }\end{array}$} & \multirow{2}{*}{$\begin{array}{c}\text { Fresh } \\
\text { weight } \\
\text { (g/plant) }\end{array}$} & \multirow{2}{*}{$\begin{array}{c}\text { Dry weight } \\
\text { (g/plant) }\end{array}$} \\
\hline $\begin{array}{c}\text { Soil } \\
\text { application }\end{array}$ & $\begin{array}{l}\text { Foliar } \\
\text { application }\end{array}$ & & & & \\
\hline \multirow{5}{*}{$\begin{array}{c}48 \mathrm{~kg} \\
\mathrm{~K}_{2} \mathrm{O} / \mathrm{fed}\end{array}$} & Control & 44.85 & 2.47 & 234.78 & 24.56 \\
\hline & $1 \% \mathrm{~K}_{2} \mathrm{O}$ & 49.88 & 2.52 & 271.36 & 31.72 \\
\hline & Micronutrients & 46.45 & 2.50 & 266.26 & 30.65 \\
\hline & $1 \% \mathrm{~K}_{2} \mathrm{O}+$ micro & 53.29 & 2.89 & 301.97 & 36.15 \\
\hline & Mean & 48.62 & 2.59 & 268.59 & 30.65 \\
\hline \multirow{5}{*}{$\begin{array}{c}72 \mathrm{~kg} \\
\mathrm{~K}_{2} \mathrm{O} / \mathrm{fed}\end{array}$} & Control & 51.08 & 2.90 & 304.78 & 36.79 \\
\hline & $1 \% \mathrm{~K}_{2} \mathrm{O}$ & 55.56 & 2.97 & 314.16 & 41.28 \\
\hline & Micronutrients & 54.56 & 2.90 & 307.05 & 38.53 \\
\hline & $1 \% \mathrm{~K}_{2} \mathrm{O}+$ micro & 58.20 & 2.93 & 316.51 & 45.01 \\
\hline & Mean & 54.85 & 2.93 & 310.63 & 40.38 \\
\hline \multirow{5}{*}{$\begin{array}{c}96 \mathrm{~kg} \\
\mathrm{~K}_{2} \mathrm{O} / \mathrm{fed} .\end{array}$} & Control & 56.22 & 2.97 & 332.84 & 42.17 \\
\hline & $1 \% \mathrm{~K}_{2} \mathrm{O}$ & 64.56 & 3.33 & 337.34 & 46.69 \\
\hline & Micronutrients & 62.29 & 2.97 & 335.47 & 45.05 \\
\hline & $1 \% \mathrm{~K}_{2} \mathrm{O}+$ micro & 68.20 & 3.67 & 340.44 & 47.39 \\
\hline & Mean & 62.82 & 3.23 & 336.52 & 45.30 \\
\hline \multirow{4}{*}{$\begin{array}{l}\text { Mean of foliar } \\
\text { treatment }\end{array}$} & Control & 50.72 & 2.78 & 290.80 & 34.14 \\
\hline & $1 \% \mathrm{~K}_{2} \mathrm{O}$ & 56.67 & 2.94 & 307.62 & 39.65 \\
\hline & Micronutrients & 54.44 & 2.79 & 302.93 & 37.84 \\
\hline & $1 \% \mathrm{~K}_{2} \mathrm{O}+$ micro & 59.90 & 3.16 & 319.64 & 42.74 \\
\hline \multirow{3}{*}{ L.S.D. at $5 \%$} & $\mathrm{~K}$ levels & 2.65 & n.s & 24.36 & 0.33 \\
\hline & $1 \% \mathrm{~K}_{2} \mathrm{O}$ \& micro & 1.52 & n.s & 16.28 & 0.46 \\
\hline & Interaction & 2.17 & n.s & n.s & n.s \\
\hline
\end{tabular}


Also, foliar application of $1 \% \quad \mathrm{~K}_{2} \mathrm{O}$ combined with mixture of $\mathrm{Fe}, \mathrm{Zn}$ and $\mathrm{Mn}$ has significant increases in the plant height, foliage fresh and dry weight /plant compared with the control. In this connection, Sangakkara et al. (2000) attributed the increase in the growth of potato plants for the role of $\mathrm{K}$ in biochemical pathways in plants and in increasing the photosynthetic rates, $\mathrm{CO}_{2}$ assimilation and facilitates carbon movements. Marschner (2012) reported that $\mathrm{K}$ plays a crucial role in turgor regulation within the guard cells during stomata movement. Potassium is an important nutrient for plant meristematic growth and physiological functions, including regulation of water and gas exchange in plants, protein synthesis, enzyme activation, photosynthesis and carbohydrate translocation in plants. Also root growth promotion by increased appropriate K supply under $\mathrm{K}$ deficient soil was found to increase the root surface that was exposed to soil as a result of increased root water uptake (Roemheld and Kirkby2010). The effect of microelements $(\mathrm{Fe}+\mathrm{Zn}+\mathrm{Mn}$ ) spraying was highly significant on plant height, foliage fresh weight/plant and dry weight (Table 2). The enhancement of growth as a result of $\mathrm{Zn}$ spray may be explained by the fact that it plays a role in tryptophan amino acid synthesis which is the precursor of endogenous natural hormone (IAA) which is necessary for cell division and cell enlargement (Singh and Singh, 1995). Zinc is recognized as an essential component of a lot of enzymes as dehydrogenases, proteinases and peptidases. It has an effect on electron transfer reactions including those in the kreb's cycle and subsequently an energy production in the plant thus, encourages growth characters of plants. Donnini et al. (2003) indicated that Fe plays a main role in the photosynthetic process in plant and cell metabolism leading to get a better growth and flowering, and/or to its role in the formation of chlorophyll molecule which leads to a high growth. Mengle and Kirkby (1982) also pointed out that the most important function of manganese is related to the oxidation-reduction processes. It can be used as a cofactor of many enzymes that act on phosphorylated substrates, also it plays a role in regulating the level of auxins in plant tissues by activating the auxin oxidase system (Russell, 1989). The effect of interaction among $\mathrm{K}$ rates, foliar spraying with $\mathrm{K}$ and micronutrients was insignificant on number of main stems/plant, fresh weight/plant and dry weight/plant.

\section{2-Yield and its components}

On the perusal of yield attributing, data presented in Table (3) and Fig. (1) showed that it is evident that the number and weight of tuber per plant were significantly increased by increasing $\mathrm{K}$ rate over $48 \mathrm{~kg}$ $\mathrm{K}_{2} \mathrm{O} / \mathrm{fed}$. with no significant difference between 72 and $96 \mathrm{~kg} \mathrm{~K} \mathrm{O} / \mathrm{fed}$., while average of tuber weight and tuber yield /fed. were significantly increased by increasing $\mathrm{K}$ rate up to the highest rate $\left(96 \mathrm{~kg} \mathrm{~K}_{2} \mathrm{O} / \mathrm{fed}\right.$. In comparison with the lowest level $(48 \mathrm{~kg} \mathrm{~K} 2 \mathrm{O}$ /fed.), increasing $\mathrm{K}$ level to $72 \mathrm{~kg} \mathrm{~K} 2 \mathrm{O} / \mathrm{fed}$. increased both average tuber weight and tuber yield /fed. by 19.66 and $6.36 \%$ respectively, while these increases reached to 31.94 and $10.46 \%$ by increasing $\mathrm{K}$ level to $96 \mathrm{~kg} \mathrm{~K} 2 \mathrm{O} / \mathrm{fed}$.

These results might be due to the increase in vegetative growth and dry matter as a result of the sufficient application and the efficient absorption of $\mathrm{K}$ which were coupled together to promote the production of more photosynthates required for good tuber yield. The previous studies also proved that $\mathrm{K}$ plays a major role in many physiological and biochemical processes such as cell division and elongation, enzyme activation, stabilization of the native conformation of enzymes and possibly turgor, metabolism of carbohydrates and protein compounds. The obtained results are supported by those of Gunadi (2009). 
Table 3. Effects of soil and foliar applications of potassium and micronutrients and their interactions on total tuber yield and its components (mean of two seasons).

\begin{tabular}{|c|c|c|c|c|c|}
\hline \multicolumn{2}{|c|}{ Treatments } & \multirow{2}{*}{$\begin{array}{c}\text { Tuber } \\
\text { number/plant }\end{array}$} & \multirow{2}{*}{$\begin{array}{c}\text { Tuber } \\
\text { weight } \\
\text { (g/plant) }\end{array}$} & \multirow{2}{*}{$\begin{array}{c}\text { Tuber } \\
\text { weight }(\mathrm{g})\end{array}$} & \multirow{2}{*}{$\begin{array}{c}\text { Total yield } \\
\text { (t/fed) }\end{array}$} \\
\hline $\begin{array}{c}\text { Soil } \\
\text { application }\end{array}$ & $\begin{array}{c}\text { Foliar } \\
\text { application }\end{array}$ & & & & \\
\hline \multirow{5}{*}{$48 \mathrm{~kg} \mathrm{~K}{ }_{2} \mathrm{O} / \mathrm{fed}$} & Control & 6.67 & 776.33 & 107.50 & 13.89 \\
\hline & $1 \% \mathrm{~K}_{2} \mathrm{O}$ & 8.00 & 879.37 & 112.33 & 14.83 \\
\hline & Micronutrients & 7.67 & 840.00 & 110.85 & 14.47 \\
\hline & $1 \% \mathrm{~K}_{2} \mathrm{O}+$ micro & 8.67 & 881.30 & 115.33 & 15.27 \\
\hline & Mean & 7.75 & 844.25 & 111.50 & 14.62 \\
\hline \multirow{5}{*}{$72 \mathrm{~kg} \mathrm{~K}{ }_{2} \mathrm{O} / \mathrm{fed}$. } & Control & 8.00 & 904.72 & 121.67 & 15.19 \\
\hline & $1 \% \mathrm{~K}_{2} \mathrm{O}$ & 8.33 & 941.09 & 139.00 & 15.49 \\
\hline & Micronutrients & 8.00 & 914.11 & 131.67 & 15.40 \\
\hline & $1 \% \mathrm{~K}_{2} \mathrm{O}+$ micro & 8.67 & 969.74 & 141.33 & 16.13 \\
\hline & Mean & 8.25 & 932.42 & 133.42 & 15.55 \\
\hline \multirow{5}{*}{$96 \mathrm{~kg} \mathrm{~K}{ }_{2} \mathrm{O} / \mathrm{fed}$} & Control & 8.33 & 954.18 & 144.67 & 15.74 \\
\hline & $1 \% \mathrm{~K}_{2} \mathrm{O}$ & 8.67 & 973.07 & 147.00 & 15.95 \\
\hline & Micronutrients & 8.33 & 966.78 & 145.67 & 16.27 \\
\hline & $1 \% \mathrm{~K}_{2} \mathrm{O}+$ micro & 9.00 & 983.07 & 151.11 & 16.66 \\
\hline & Mean & 8.58 & 969.28 & 147.11 & 16.15 \\
\hline \multirow{4}{*}{$\begin{array}{l}\text { Mean of foliar } \\
\text { treatment }\end{array}$} & Control & 7.67 & 878.41 & 124.61 & 14.94 \\
\hline & $1 \% \mathrm{~K}_{2} \mathrm{O}$ & 8.33 & 931.18 & 132.78 & 15.42 \\
\hline & Micronutrients & 8.00 & 906.96 & 129.39 & 15.38 \\
\hline & $1 \% \mathrm{~K}_{2} \mathrm{O}+$ micro & 8.78 & 944.70 & 135.93 & 16.02 \\
\hline \multirow{3}{*}{ L.S.D. at $5 \%$} & $\mathrm{~K}$ levels & 0.38 & 76.38 & 7.61 & 0.40 \\
\hline & $1 \% \mathrm{~K}_{2} \mathrm{O} \&$ micro & 0.69 & 74.37 & 7.32 & 0.49 \\
\hline & Interaction & n.s & n.s & 10.46 & 0.69 \\
\hline
\end{tabular}

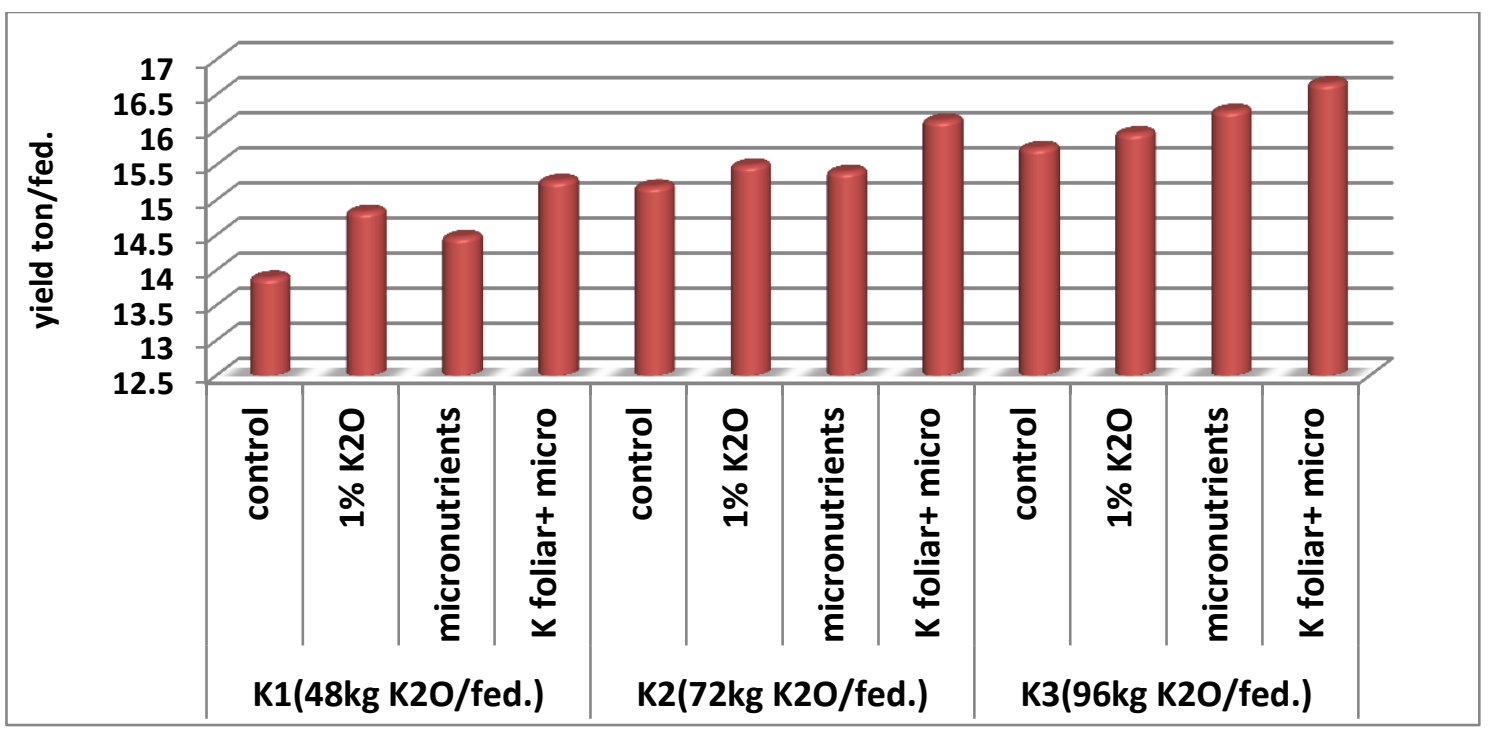

Fig. (1): Effects of foliar application of potassium and micronutrients on tuber yield under different $\mathrm{K}$ levels. 
Among foliar treatments, foliar application of $1 \% \mathrm{~K} 2 \mathrm{O}$ combined with micronutrient mixture induced significant increases in number and weight of tubers /plant as well as weight of individual tubers and tuber yield/fed. Meanwhile foliar application of either $1 \% \quad \mathrm{~K} 2 \mathrm{O}$ or micronutrient mixture alone did not show any significant effects on the above mentioned parameters as shown in Table (3). The effect of micronutrients (Fe, $\mathrm{Zn}$ and $\mathrm{Mn}$ ) on yield and its components might be attributed to their positive effect on photosynthetic process and as activators for IAA oxidase and carbohydrate assimilation. Moreover micronutrient elements play a critical role in plants that lead to increase of leaf area index and thereby increased light absorption and increase the amount of dry matter accumulation and economic yield (Ravi et al. 2008).Combined soil and foliar $\mathrm{K}$ application was also found to be better for all the yield parameters like tuber number/plant, tuber weight ( $\mathrm{g} / \mathrm{plant}$ ), average of tuber weight and total yield (t/fed) than the soil application alone.

Concerning the interaction between $\mathrm{K}$ rate added as soil application, foliar spraying with $\mathrm{K}$ and/or micronutrient mixture on yield and its components, data in Table (3) reveal that there was significant effect on average of tuber weight and total yield ( $\mathrm{t} / \mathrm{fed}$ ). However tuber number/plant and tuber weight (g/plant), were not significantly influenced by the interaction. The maximum total yield was obtained when potato plants were fertilized with $100 \% \mathrm{~K}(96 \mathrm{~kg} \mathrm{~K} 2 \mathrm{O}$ /fed.), and sprayed with $\mathrm{K}\left(1 \% \mathrm{~K}_{2} \mathrm{O}\right)$ and micronutrient mixture compared with untreated ones.

\section{3-Tuber quality}

The results in Table (4) and Fig. (2) demonstrate that specific gravity, protein and carbohydrates\% were significantly augmented by increasing $\mathrm{K}$ rates while tuber dry matter and starch contents were significantly increased by the highest $\mathrm{K}$ rate only compared with the lowest rate. The highest values of tuber quality were obtained at $100 \% \mathrm{~K}_{2} \mathrm{O}$ of the recommended rate compared with $50 \%$ of recommended rate. This could be ascribed to that $\mathrm{K}$ application activates number of enzymes involved in photosynthesis, carbohydrate metabolism and proteins and assists in the translocation of carbohydrates from leaves to tubers (Bansal and Trehan 2011). The higher yield quality in case of using of potassium may be also attributed to the role of potassium in translocation of produced photosynthetic assimilates and its accumulation in storage tubers and in turn increase the tuber weight, which consequently affect positively yield quality. The presented data in Table (4) show also, that foliar application of $1 \% \mathrm{~K}_{2} \mathrm{O}$ in combination with micronutrients significantly affected the percentage of dry matter, protein, starch and carbohydrates in potato tubers. The studied yield qualities except specific gravity were significantly affected by the interaction treatments. The maximum yield quality viz tuber dry matter (21.91\%), starch (17.71\%), total carbohydrates $(79.82 \%)$ and protein $(14.57 \%)$ were recorded in plants sprayed with $\mathrm{Fe}, \mathrm{Zn}$ and $\mathrm{Mn}$ along with foliar application of $1 \% \mathrm{~K}_{2} \mathrm{O}$ under the highest $\mathrm{K}$ level (the recommended rate). Due to metabolic role of micronutrients in synthesis of proteins, enzyme activation and metabolism of carbohydrate, utilization of fertilizers containing these element increases qualitative and quantitative performance of potato tubers. In this connection (Mousavi et al. 2007) indicated a positive influence of micronutrients ( $\mathrm{Fe}, \mathrm{Zn}$ and $\mathrm{Mn}$ ) application on yield and quantitative parameters of potato. 
Table 4. Effects of soil and foliar applications of potassium and micronutrients and their interactions on Tuber quality (mean of two seasons)

\begin{tabular}{|c|c|c|c|c|c|c|}
\hline \multicolumn{2}{|c|}{ Treatments } & \multirow{2}{*}{$\begin{array}{c}\text { Dry } \\
\text { matter } \\
\%\end{array}$} & \multirow{2}{*}{$\begin{array}{l}\text { Specific } \\
\text { gravity }^{-3}\left(\mathrm{gcm}^{-3}\right)\end{array}$} & \multirow{2}{*}{$\begin{array}{c}\text { Protein } \\
\%\end{array}$} & \multirow{2}{*}{$\begin{array}{c}\text { Starch } \\
\%\end{array}$} & \multirow[b]{2}{*}{ Carbohydrates\% } \\
\hline $\begin{array}{c}\text { Soil } \\
\text { application }\end{array}$ & $\begin{array}{l}\text { Foliar } \\
\text { application }\end{array}$ & & & & & \\
\hline \multirow{5}{*}{$\begin{array}{c}48 \mathrm{~kg} \\
\mathrm{~K}_{2} \mathrm{O} / \mathrm{fed}\end{array}$} & Control & 19.19 & 1.079 & 11.37 & 14.37 & 74.25 \\
\hline & $1 \% \mathrm{~K}_{2} \mathrm{O}$ & 20.54 & 1.082 & 12.00 & 15.55 & 75.09 \\
\hline & Micronutrients & 20.37 & 1.081 & 12.38 & 15.73 & 74.60 \\
\hline & $1 \% \mathrm{~K}_{2} \mathrm{O}+$ micro & 20.88 & 1.085 & 12.75 & 15.82 & 75.45 \\
\hline & Mean & 20.24 & 1.082 & 12.12 & 15.37 & 74.85 \\
\hline \multirow{5}{*}{$\begin{array}{c}72 \mathrm{~kg} \\
\mathrm{~K}_{2} \mathrm{O} / \mathrm{fed}\end{array}$} & Control & 20.71 & 1.085 & 12.42 & 15.51 & 76.78 \\
\hline & $1 \% \mathrm{~K}_{2} \mathrm{O}$ & 20.87 & 1.087 & 13.00 & 16.32 & 78.25 \\
\hline & Micronutrients & 20.74 & 1.086 & 12.55 & 16.15 & 77.39 \\
\hline & $1 \% \mathrm{~K}_{2} \mathrm{O}+$ micro & 21.56 & 1.088 & 14.05 & 17.00 & 79.33 \\
\hline & Mean & 20.97 & 1.087 & 13.00 & 16.24 & 77.94 \\
\hline \multirow{5}{*}{$\begin{array}{c}96 \mathrm{~kg} \\
\mathrm{~K}_{2} \mathrm{O} / \mathrm{fed}\end{array}$} & Control & 21.41 & 1.090 & 13.90 & 16.79 & 78.17 \\
\hline & $1 \% \mathrm{~K}_{2} \mathrm{O}$ & 21.55 & 1.093 & 14.36 & 17.37 & 78.60 \\
\hline & Micronutrients & 21.89 & 1.091 & 14.11 & 16.86 & 77.87 \\
\hline & $1 \% \mathrm{~K}_{2} \mathrm{O}+$ micro & 21.91 & 1.096 & 14.57 & 17.71 & 79.82 \\
\hline & Mean & 21.69 & 1.093 & 14.23 & 17.18 & 78.62 \\
\hline \multirow{4}{*}{$\begin{array}{l}\text { Mean of } \\
\text { foliar } \\
\text { treatment }\end{array}$} & Control & 20.44 & 1.085 & 12.56 & 15.56 & 76.40 \\
\hline & $1 \% \mathrm{~K}_{2} \mathrm{O}$ & 20.98 & 1.087 & 13.12 & 16.42 & 77.31 \\
\hline & Micronutrients & 21.00 & 1.086 & 13.01 & 16.25 & 76.62 \\
\hline & $1 \% \mathrm{~K}_{2} \mathrm{O}+$ micro & 21.45 & 1.090 & 13.79 & 16.84 & 78.20 \\
\hline \multirow{3}{*}{$\begin{array}{c}\text { L.S.D. at } \\
5 \%\end{array}$} & K levels & 0.82 & 0.003 & 0.34 & 1.12 & 0.95 \\
\hline & $1 \% \mathrm{~K}_{2} \mathrm{O} \&$ micro & 1.18 & 0.003 & 0.38 & 0.75 & 1.34 \\
\hline & Interaction & 1.69 & n.s & 0.54 & 1.08 & 3.69 \\
\hline
\end{tabular}

\section{4-Tuber contents of nutrients}

Data in Table (5) clearly illustrate that the addition of potassium significantly affected the uptake $(\mathrm{kg} / \mathrm{fed}$.) of $\mathrm{N}, \mathrm{P}$ and $\mathrm{K}$ in the tubers. The highest values of these macronutrients were obtained from the application of $100 \% \mathrm{~K}_{2} \mathrm{O}$ of recommended rate compared with $50 \%$ of recommended rate. Such results might be attributed to that $K$ encourages various enzymes and photosynthesis as well as plant root development, which in turn resulted in higher 
dry matter accumulation in tubers. Moreover $\mathrm{K}$ enhances translocation of metabolites synthesized from leaves to tubers. Also; data in Table (5) indicate that $\mathrm{Fe}, \mathrm{Zn}$ and $\mathrm{Mn}$ contents in the tubers were significantly increased by increasing the $\mathrm{K}_{2} \mathrm{O}$ rate. Potato plants fertilized with 75 or $100 \% \mathrm{~K}_{2} \mathrm{O}$ of recommended rate gave the higher values of $\mathrm{Fe}, \mathrm{Zn}$ and $\mathrm{Mn}$ contents compared with $50 \%$ of recommended rate. These results may be due to the effect of $\mathrm{K}_{2} \mathrm{O}$ on plant growth and consequently on the efficiency of the root in absorbing various nutrients. The obtained results are in agreement with those reported by Allison et al. (2001) and Westermann (2005).

As regard to the effect of either foliar spray of $\mathrm{K}$ or micronutrients singly or combined on nutrient contents in the potato tubers, data in Table (5) indicate that foliar spray with $\mathrm{K}_{2} \mathrm{O}$ and /or micronutrient application caused the highest significant increase in $\mathrm{N}, \mathrm{P}$ and $\mathrm{K}$ in the tubers compared with the untreated control.

Data in Table (5) reveal that foliar spray of $\mathrm{K}_{2} \mathrm{O}$ or mixture of micronutrients singly or combined had significant positive effect on $\mathrm{Fe}, \mathrm{Zn}$ and $\mathrm{Mn}$ contents in the tubers compared with the control. The interaction between $\mathrm{K}_{2} \mathrm{O}$ rates, and foliar spraying with $\mathrm{K}_{2} \mathrm{O}$ along with micronutrients on uptake of $\mathrm{N}, \mathrm{K}_{2} \mathrm{O}$ in the tubers of potato plant was significant. The highest values of the estimated macro and micronutrients were achieved by spraying potato plants with $1 \%$ $\mathrm{K}_{2} \mathrm{O}$ along with foliar spraying of a mixture of $\mathrm{Fe}, \mathrm{Zn}, \mathrm{Mn}$ under $96 \mathrm{~kg} \mathrm{~K}_{2} \mathrm{O} / \mathrm{fed}$. as soil application .

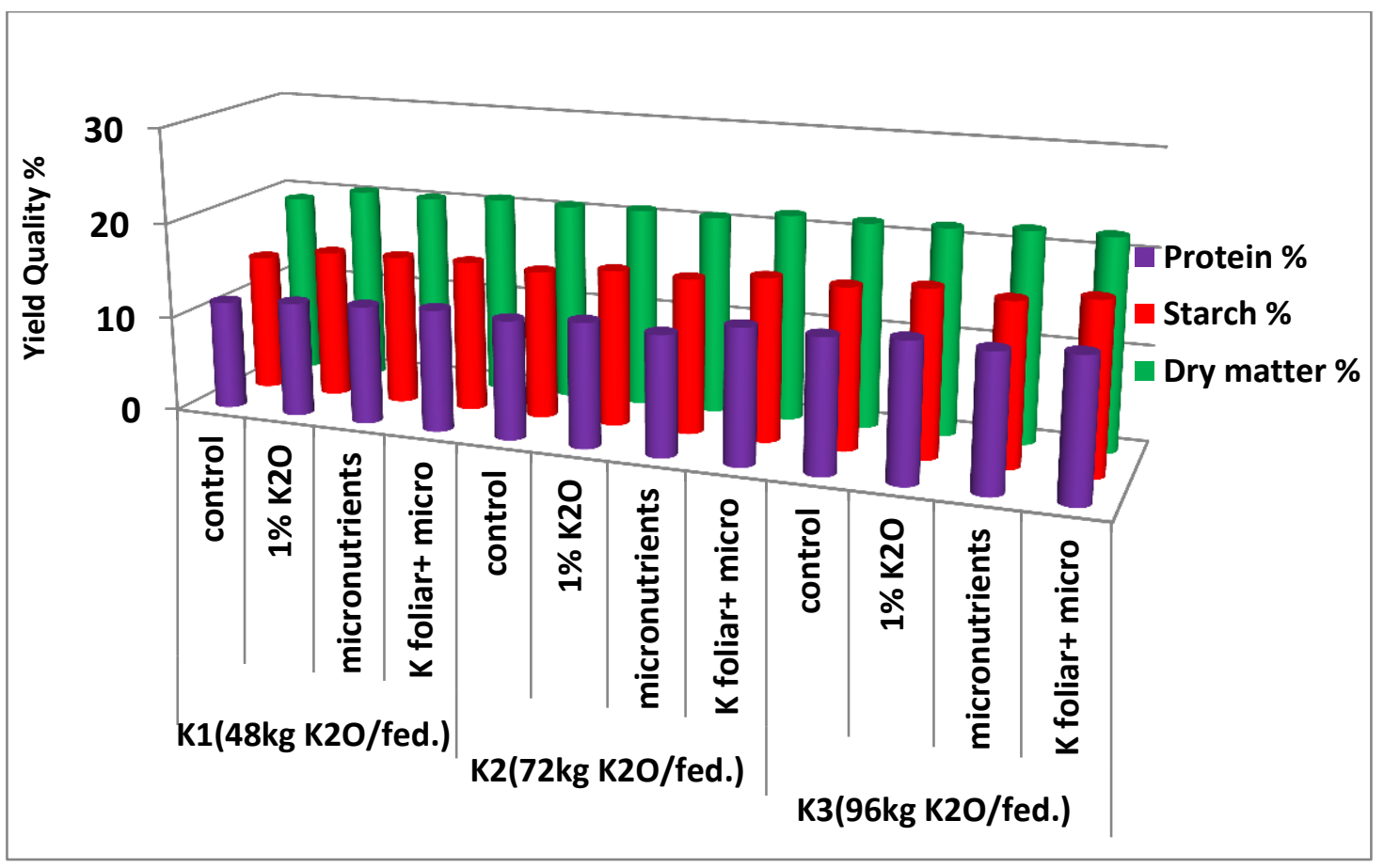

Fig. (2): Effects of foliar application of potassium and micronutrients under $\mathrm{K}$ levels on tuber quality 
Table 5. Effects of soil and foliar applications of potassium and micronutrients and their interactions on Tuber nutrient content (mean of two seasons).

\begin{tabular}{|c|c|c|c|c|c|c|c|}
\hline \multicolumn{2}{|c|}{ Treatments } & \multicolumn{3}{|c|}{$\begin{array}{l}\text { Macronutrients uptake } \\
(\mathrm{kg} / \mathrm{fed} .)\end{array}$} & \multicolumn{3}{|c|}{ Micronutrients $\left(\mathrm{mg} \mathrm{kg}^{-1}\right)$} \\
\hline $\begin{array}{c}\text { Soil } \\
\text { application }\end{array}$ & $\begin{array}{l}\text { Foliar } \\
\text { application }\end{array}$ & $\mathrm{N}$ & $P$ & K & $\mathrm{Fe}$ & $\mathrm{Mn}$ & $\mathrm{Zn}$ \\
\hline \multirow{5}{*}{$\begin{array}{c}48 \mathrm{~kg} \\
\mathrm{~K}_{2} \mathrm{O} / \mathrm{fed}\end{array}$} & Control & 52.70 & 6.93 & 58.08 & 64.15 & 33.68 & 40.52 \\
\hline & $1 \% \mathrm{~K}_{2} \mathrm{O}$ & 63.57 & 8.06 & 70.66 & 68.79 & 42.14 & 46.74 \\
\hline & Micronutrients & 63.46 & 7.80 & 65.20 & 72.75 & 47.44 & 58.81 \\
\hline & $1 \% \mathrm{~K}_{2} \mathrm{O}+$ micro & 70.66 & 8.25 & 75.50 & 87.22 & 58.48 & 66.58 \\
\hline & Mean & 62.60 & 7.76 & 67.36 & 73.23 & 45.43 & 53.16 \\
\hline \multirow{5}{*}{$\begin{array}{c}72 \mathrm{~kg} \\
\mathrm{~K}_{2} \mathrm{O} / \mathrm{fed}\end{array}$} & Control & 67.95 & 8.22 & 75.17 & 81.67 & 37.42 & 41.33 \\
\hline & $1 \% \mathrm{~K}_{2} \mathrm{O}$ & 73.03 & 9.18 & 79.70 & 78.89 & 47.33 & 47.78 \\
\hline & Micronutrients & 69.76 & 8.70 & 78.06 & 94.59 & 61.22 & 73.97 \\
\hline & $1 \% \mathrm{~K}_{2} \mathrm{O}+$ micro & 84.94 & 9.54 & 88.04 & 107.47 & 72.74 & 76.04 \\
\hline & Mean & 73.92 & 8.91 & 80.24 & 90.66 & 54.68 & 59.78 \\
\hline \multirow{5}{*}{$\begin{array}{c}96 \mathrm{~kg} \\
\mathrm{~K}_{2} \mathrm{O} / \mathrm{fed}\end{array}$} & Control & 81.42 & 9.61 & 83.64 & 89.11 & 37.69 & 47.67 \\
\hline & $1 \% \mathrm{~K}_{2} \mathrm{O}$ & 85.82 & 10.78 & 85.59 & 94.97 & 53.22 & 59.11 \\
\hline & Micronutrients & 87.36 & 9.62 & 90.29 & 107.22 & 73.07 & 78.78 \\
\hline & $1 \% \mathrm{~K}_{2} \mathrm{O}+$ micro & 92.49 & 11.19 & 94.55 & 113.18 & 81.19 & 82.33 \\
\hline & Mean & 86.77 & 10.30 & 88.52 & 101.12 & 61.30 & 66.97 \\
\hline \multirow{4}{*}{$\begin{array}{l}\text { Mean of } \\
\text { foliar } \\
\text { treatment }\end{array}$} & Control & 67.36 & 8.25 & 72.29 & 78.31 & 36.26 & 43.17 \\
\hline & $1 \% \mathrm{~K}_{2} \mathrm{O}$ & 74.14 & 9.34 & 78.65 & 80.88 & 47.56 & 51.21 \\
\hline & Micronutrients & 73.52 & 8.71 & 77.85 & 91.52 & 60.58 & 70.52 \\
\hline & $1 \% \mathrm{~K}_{2} \mathrm{O}+$ micro & 82.70 & 9.66 & 86.03 & 102.63 & 70.80 & 74.98 \\
\hline \multirow{3}{*}{ L.S.D. at $5 \%$} & K levels & 4.61 & 0.70 & 6.21 & 5.53 & 1.62 & 2.41 \\
\hline & $1 \% \mathrm{~K}_{2} \mathrm{O} \&$ micro & 6.34 & 0.82 & 6.60 & 2.32 & 2.25 & 2.56 \\
\hline & Interaction & 9.06 & n.s & 9.43 & 3.31 & 3.22 & 3.66 \\
\hline
\end{tabular}

\section{CONCLUSION}

The positive perspective of this study emphasized the importance of potassium fertilization for potato. It can be concluded that foliar application of $1 \% \mathrm{~K}_{2} \mathrm{O}$ and mixture of micronutrients ( $\mathrm{Fe}, \mathrm{Zn}$ and $\mathrm{Mn}$ ) had a beneficial role and appears to be of great importance in enhancing growth, yield and nutrient contents of potato tubers. Hence, application of $72 \mathrm{~kg} \mathrm{~K} \mathrm{~K}_{2} \mathrm{O} / \mathrm{fed}$ soil application combined with $1 \% \mathrm{~K}_{2} \mathrm{O}$ plus mixture of micronutrients as foliar application are found to be the appropriate rates for optimum productivity of potato plants in sandy soil with no significant differences between this treatment and that of under soil $\mathrm{K}$ application at $96 \mathrm{~kg} \mathrm{K20} / \mathrm{fed}$. in most cases. 


\section{REFERENCES}

Abou El-Nour, E.A.A. (2002). Can supplemented potassium foliar feeding reduce the recommended soil potassium. Pakistan J. of Biol. Sci. 5(3): 259-262

Allison, M.F., J.H. Fowler and E.J. Allen (2001). Responses of potato (Solanum tubersum L.) to potassium fertilizers. J. of Agric. Sci., 136(4):407-426.

Asmaa, R. M., and M. H. Magda (2010). Increasing productivity of potato plants (solanum tuberosum, L.) By using potassium fertilizer and humic acid application. I. J. Academic Res. (2): 8388.

Bansal, S.K. and S.P. Trehan (2011). Effect of potassium on yield and processing quality attributes of potato. Karnataka $\mathrm{J}$. Agric. Sci. (24): 48-54.

Chapman, H.D. and P.F. Pratt (1961). Methods of Analysis for Soil, Plant and Waters. Univ. Calif. Division of Agric. Sci., pp. 16 -38, 97 - 99 and 161-174.

Chapman, H.D. and P.F. Pratt (1982). Methods of Plant Analysis, I. Methods of Anaylsis for Soil, Plant and Water. Chapman Publishers, Riverside, California, USA.

Cottenie, A., M. Verloo, L. Kiekens, G. Velge and R. Camerlynck (1982). "Chemical Analysis of Plants and Soils". Lab.Agrochem,State University Ghent, Belgium.

Donnini, S., A. Castagnal, L. Guidi, G.I. Zocchi and A. Ranieri (2003). Leaf responses to reduce iron availability in two tomato genotypes: T 3238 FER (Iron Efficient) and $\mathrm{T} 3238$ FER (Iron Inefficient). J. Plant Nutrition, 26(10): 2137-2148.

Dubois, M., K.A. Gilles, J.K. Hamition and P.A Rebers (1956). Colorimetric method for determination of sugars and related substances. Anal. Chem., 28:350-356.

Gomez, K. A. and A. A. Gomez (1984). "Statistical Procedures for Agricultural Research". John Wiley and Sons, Inc.,
New York.pp:680. (C F computer search).

Gunadi, N. (2009). Response of potato to potassium sources and application methods in andonsisols of Wes Java. Indonesian J. Agric. Sci., 10 (2): 62-72. Food and Agriculture Organization (FAO) (2007).

Hiller, K. L. (1995). Foliar fertilization bumps potato yields in northwest. Rate and timing of application, plus host of other considerations, are critical in applying foliar to potatoes. Fluid J., 3 (3): 29-30.

Klute, A. (ed.). (1986). Methods of Soil Analysis. Part 1. Physical and Microbiological Methods. $2^{\text {nd }}$ edition. Agron. Monogr. 9. ASAand SSSA, Madison, WI.

Marschner, H. (1995). Mineral Nutrition of Higher Plants. $2^{\text {nd }}$ ed., reprinted 2008. Academic Press, Amsterdam, The Netherlands.

Marschner, P. (2012). Mineral Nutrition of Higher Plants, 3rd ed.; Academic Press: London, UK; pp. 178-189.

Mengel, K. (1997). Impact of potassium on crop yield and quality with regard to economical and ecological aspects. In: Proceeding of IPI Regional Workshop on: Food Security in the WANA Region, The essential need for balanced fertilization, held at Bornova, Lamir Turkey, and International Potash institute Bern, Switzerland, pp.157-174.

Mengel, K. (2007). Potassium, pp. 91-120. In: A.V. Barker and D.J. Pilbeam (eds.). Handbook of plant nutrition. CRC Taylor and Francis Group, Boca Raton, Florida

Mengle, K. and E.A. Kirkby (1982). Principles of Plant Nutrition. $3^{\text {rd }}$ ed., International Potash Institute, Swizerland.

Mengel, K. and E.A. Kirkby (2001). Principles of Plant Nutrition. 5th ed. Kluwer Academic Publisher, Dordrecht, The Netherlands.

Mousavi, S.R., M. Galavi and G. Ahamad (2007). Effect of zinc and manganese 
foliar application on yield, quality and enrichment on potato (Solanum tuberosum L.).Asian J. PI.Sci., 6(8): 1256- 1260.

Navarre, D.A., A. Goyer and R. Shakya (2009). Nutritional value of potatoes: phytonutrient and mineral content, pp. 395-424. In: Singh, J. and L. Kaur (eds.). Advances in Potato chemistry and technology. Academic Press, New York.

Page, A. L., R. H. Miller and D. R. Keeny (ed.) (1982). Methods of Soil Analysis, part2. Chemical and Microbiological Properties. Amer. Soc. of Agronomy. Madison, Wisconsin, USA.

Ravi, S., H.T. Channal, N.S. Hebsur, B.N. Patil and P.R. Dharmatti (2008). Effect of sulphur, zinc and iron nutrition on growth, yield, nutrient uptake and quality of safflower (Carthamus tinctorius L.). Karnataka J. Agric. Sci., 21(3): 382-385.

Roemheld, V. and M.M. El-Fouly (1999). Foliar nutrient application: Challenge and limits in crop production. Proc. 2nd International Workshop on Foliar Fertilization, April 4-10 Bangkok, Thailand, pp. 1-32.

Roemheld, V. and E.A. Kirkby (2010). Research on potassium in agriculture: needs and prospect. Plant and Soil 335:155-180.

Russell, S.E.W. (1989). "Soil Conditions and Plant Growth", 11th ed., Dept. of Soil Sci., Univ. of Reading, Longman Group, UK Ltd.

Ryan, J., S. Garabet, K. Harmsen and A. A. Rashid (1996). Soil and Plant Analysis Manual Adapted for the west Asia and North Africa Region. ICARDA, Aleppo, Syria. 140pp.

Sangakkara, U.R., M. Frehner and J. Nosberger (2000). Effect of soil moisture and potassium fertilizer on shoot water potential, photosynthesis and partitioning of carbon in mungbean and cowpea. J. Agron. Crop Sci., 185: 201-207.

Singh, D. and V. Singh (1995). Effect of potassium, zinc and sulphur on growth characters, yield attributes and yield of soybean (Glycine max L.). Indian J. Agron., 40(2): 223-227.

Talburt, W.F. and O. Smith (1975). Potato Processing. $3^{\text {th }}$ ed. The AVI Publishing Company, Westport, CT.

Westermann, D.T. (2005). Nutritional requirements of potatoes. Am. J. Potato Res. 83: 301-307. 
إستجابة نباتات البطاطس للتسميد البوتاسي والعناصر الصغرى

\section{داليا عدروز سيد}

معهز بحوث الأراضي والمياه والبيئة - مركز البحوث الزراعية - الجيزة - مصر

الملخص العربى

اقيمت تجربتان حقليتان بقرية الشعراوى بمنطقة البستان - النوبارية محافظة البحيرة - مصر خلال الموسم

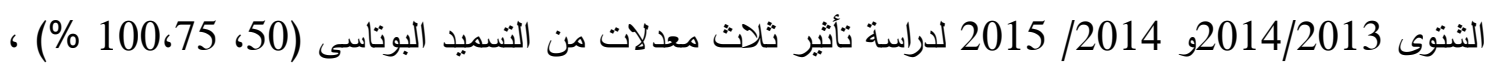

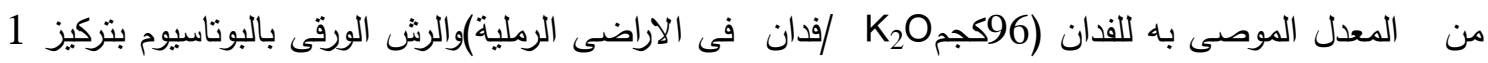

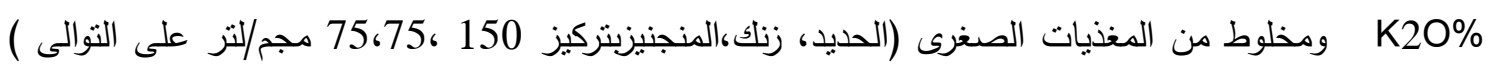
وتفاعلاتهم على النمو والمحصول ومكوناته والمتوى الكيماوي للارنات فى البطاطس صنف أسبونتا .

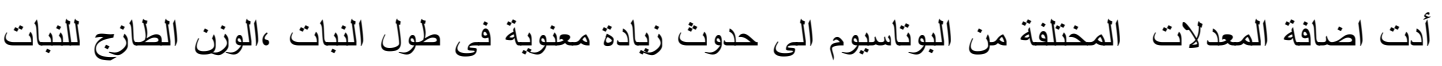

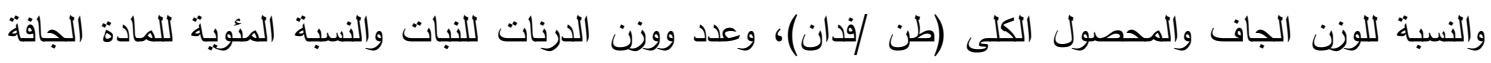

والنشا ومحتوى البروتين والكربوهيدرات الكلية فى الدرنات بالاضافة الى محتوى العناصر المعدنية فى الدرنة.

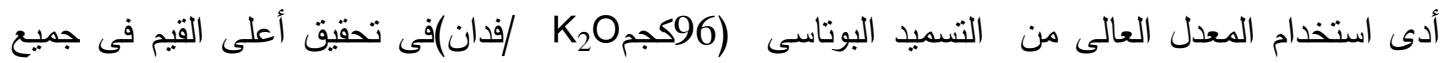
قياسات النمو المدروسة مقارنتة بالمعاملات الاخرى.اوضحت النتائج ايضا ان الرش الورقى

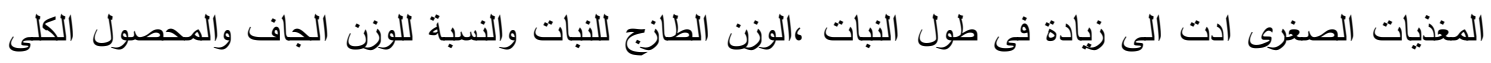
(طن /فدان)، وعدد ووزن الدرنات للنبات والنسبة المئوية للمادة الجافة والنشا ومحتوى البروتين والكربوهيدرات الكلية فى الدرنات بالاضافة الى محتوى العناصر المعدنية فى الدرنة مقارنة بالكنترول. أظهرت النتائج أن هناك تأثثرات

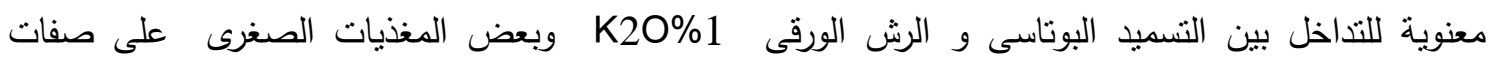
المحصول بالاضافة الى بعض المواد الحيوية ومحتوى العناصر المعدنية. اتجهت معاملة التفاعل المشترك بين مستوى التسميد الأرضى بالبوتاسيوم عند المعدل 75\% من المعدل الموصى به للفدان والرش الورقى بالبوناسيوم بتركيز 1 K2O\% وبعض المغذيات الصغرى إلى زيادة فى معظم صفات النمو والمحصول الكلى (طن /فدان) وذللك مقارنة بالمعدل العالي من التسميد البوتاسي الارضي ( 100\%) من المعدل الموصى به للفدان بمفرده بدون فروق معنوية بين هذه المعاملة وتلك التى كانت تحت معدل 96 كجم K2O /فدان فى معظم الحالات. 